\title{
Epiphytic Bacterial Communities in Seagrass Meadows of Oligotrophic Waters of Andaman Sea
}

\author{
Amrit Kumar Mishra*, Raju Mohanraju \\ Department of Ocean Studies and Marine Biology, School of Life Sciences, Pondicherry University, Brookshabad Campus, \\ Port Blair, India \\ Email: ^amritkumarishra@gmail.com
}

How to cite this paper: Mishra, A.K. and Mohanraju, R. (2018) Epiphytic Bacterial Communities in Seagrass Meadows of Oligotrophic Waters of Andaman Sea. Open Access Library Journal, 5: e4388. https://doi.org/10.4236/oalib.1104388

Received: January 31, 2018

Accepted: March 2, 2018

Published: March 5, 2018

Copyright (c) 2018 by authors and Open Access Library Inc.

This work is licensed under the Creative Commons Attribution International License (CC BY 4.0).

http://creativecommons.org/licenses/by/4.0/

\begin{abstract}
The epiphytic microbial communities of seagrass (Cymodocea rotundata and Thalassia testudinum) along with sediments and seawater of the seagrass ecosystem of Andaman Sea were assessed for heterotrophic bacterial communities. Young leaves of $C$. nodosa and T. testudinum sediments and water samples were collected from two different locations at Burmanala and Havelock island. Young leaves were swabbed and transferred into Alkaline peptone water along with $1 \mathrm{gm}$ of sediments and $1 \mathrm{ml}$ of seawater for initial microbial enrichments, followed by culture of microbes in Salt Yeast Extract Agar. Thiosulphate Citrate Bile Salt agar was used for seagrass leaves, sediments and water for culturing of Vibrio like microbes. The observed colonies were morphologically (colour) identified first and then further identification was done by Gram staining and various biochemical tests. Sediment bacterial count was 10 -fold higher than seagrass and water column communities. Morphologically $29 \%$ of total bacterial colonies identified were of grey and white colour. $T$. testudinum bacterial epiphytes were 2 -fold higher than $C$. rotundata communities. Gram negative bacterial isolates of Pseudomonas, Vibrios and Aeromonas dominated the bacterial colonies than gram positive bacteria of Bacillus and Micrococcus. Vibrios were only observed on seagrass leaves. Seagrass harboured more gram positive bacterial colonies than gram negative, which were dominated in the sediments of seagrass ecosystem. The bacterial communities of landward site of Burmanala and Havelock were similar whereas 2 -fold higher communities were observed at the seaward site of Havelock site on T. testudinum. Seagrass ecosystem bacterial epiphytic communities are diverse in oligotrophic waters.
\end{abstract}

\section{Subject Areas}

Marine Biology 


\section{Keywords}

Intertidal Communities, Microbes, Oligotrophic Waters, Heterotrophic Bacteria

\section{Introduction}

The Andaman and Nicobar group of Islands are situated in the South-east of Indian subcontinent in the Bay of Bengal, Indian Ocean. The Andaman Sea surrounding these islands comprises of a rich marine diversity of flora and faunal assemblages [1]. The intertidal flora of these islands is dominated by seagrass ecosystem with patches of various seaweeds [2]. Seagrass ecosystems are distributed worldwide [3] [4] and are highly productive and dynamic coastal ecosystems [3] [5]. They provide various ecosystem services, such as nursery and breeding grounds for fishes, carbon storage, nutrient cycling and serve as food for many herbivore fishes, sea turtles and sea mammals [6] [7]. They are highly productive ecosystems particularly in oligotrophic waters [3] [4]. This high productivity in seagrass ecosystem also generates a great amount of organic matter and serves as a good substratum for a rich diversity of microorganisms forming an integral part of the seagrass ecosystem [8]. These microbes (i.e. bacteria) play important role in recycling of organic materials [3].

Microorganisms of bacterial origin play a significant role in productivity and degradation of organic matter, i.e., microbial loop [9]. Microbial loops are essential in all types of marine ecosystems but most important in coastal oligotrophic waters where the available nutrients are less and the ecosystem depends on microbes for recycling of organic matter [3] [10]. These microbial communities form a significant part of the epiphytic communities on seagrass ecosystem consisting of bacteria, fungi and protozoa [8] [11]. The distribution and abundance of epiphytes on seagrass leaves depend mainly on the morphology and life span of the portion colonized by epiphytes [8] such as the young leaves or mature leaves. These bacterial communities of seagrass leaves are diverse and include various genus of Alteromonas, Brochothrix, Moraxella, Marinobacter, Pseudomonas and Vibrio [12]. Instead of the entire leaf, bacterial epiphytes prefer young leaf tips and mature leaf bases, which has been observed in Zostera marina and Posidonia oceanica leaf tips and base [12] [13]. This apico-basal pattern of epiphyte colonization is also observed for other seagrass species like Cymodocea rotundata and T. hemprichii [8].

These epiphytic communities not only contribute to the net community production of seagrass ecosystem but also support other functions, such as herbivory and transfer of energy to higher trophic levels [14]. Epiphytes also help seagrass in nitrogen fixation [8] [15] and nutrient cycling [16]. [15] reported 4\% $38 \%$ of nitrogen needed for primary production by Thalassia testudinum is provided by the epiphytic cyanobacteria on their leaves. Similarly, $17 \%$ of $\mathrm{NH}_{4}^{+}$ removed form water column in $T$. testudinum meadows is due to the presence of 
bacterial epiphytes on their leaves [16].

Most studies on bacterial epiphytes of seagrass have considered individual seagrass species [17] [18] [19] [20] or a combination of seagrass and sediments from seagrass ecosystem [13] [21] [22]. Individual seagrass species have shown a wide range of bacterial epiphytes associated within the seagrass leaves preferring the apico-base pattern, for example, Halophila stipulacea of Red Sea was observed with Cyanobacteria and nitrogen fixing bacteria on leaves [17], whereas Bacillus, Vibrios, Micrococcus and Staphylococcus sp. were observed on $H$. ovalis, $H$. uninervis and H. stipulacea of Jordan [23]. Similarly, sulphur-oxidising Gammapro teobacteria and sulfur-reducing Deltaproteobacteria were observed on Zostera marina leaves from Chesapeake Bay [20] and Z. noltii from Bassin d' Arcachon [19], whereas Cyanobacteria sp. was observed in the leaves of Thalassia and Cymodocea sp. of Tanzania [5]. The sediment bacterial communities of seagrass ecosystem were more dominated with organicmatter cycling communities such as, Desulfovibrio and Acetobacter sp. in sediments of $H$. wrightii meadows of Florida coast [18], sulfate-reducing bacteria in Posidonia oceanica meadows of Mediterranean Sea [24] and T. testudinum and H. wrightii of Florida Bay [25]. However, few studies also have been carried on seagrass and sediments together for bacterial epiphytes, such as T. testudinum of Bahamas [21], Posidonia oceanica of Mediterranean Sea (Novak, 1984) and T. testudinum of Florida Bay [22].

Considering the importance of Indian seagrass ecosystem and scarce studies on bacterial epiphytic population of oligotrophic waters of Andaman Sea, we try to assess the heterotrophic bacterial communities that survive on seagrass C. rotundata and T. testudinum leaves as epiphytes and the associated water and sediments within seagrass meadows of Andaman Sea to have an overview of the microbial diversity of seagrass meadows in oligotrophic waters.

\section{Materials and Methods}

\subsection{Study Area}

Two study areas were selected with seagrass meadows of Andaman and Nicobar Islands in Andaman Sea, India. Both stations are situated in low-lying areas with similar hydrodynamic conditions, exposed twice in a day during low tides. At each location two sites were chosen, one close towards the land side and one towards the open ocean. Burmanala (11 $\left.33^{\prime} 22.293^{\prime \prime N} \mathrm{~N} 092^{\circ} 43^{\prime} 43.961^{\prime \prime} \mathrm{E}\right)$ is situated on the South-east coast of Andaman island. This low-lying area gets exposed during low tides and the luxuriant growth of seagrass Cymodocea rotundata is observed in this intertidal ecosystem. Havelock $\left(11^{\circ} 58^{\prime} 44.45^{\prime \prime} \mathrm{N}\right.$ : $\left.92^{\circ} 56^{\prime} 36.86^{\prime \prime} \mathrm{E}\right)$ is situated in north east of Andaman island. This intertidal region is dominated by seagrass Thalassia testudinum.

\subsection{Sample Collection}

Seagrass leaves (C. rotundata and T. testudinum) were collected from both 
Burmanala and Havelock sampling stations (2 sites each) during low tide. Young and slightly mature seagrass leaves were plucked by sterile forceps. Seawater samples $(n=3)$ were collected in sterile screw cap bottles for all four sites of each station. Sediment samples $(\mathrm{n}=3)$ were collected by scooping out the upper $1 \mathrm{~cm}$ of sediment using a spatula from the same area seagrass were collected and stored in sterile glass containers. Water, sediment and seagrass were stored in portable ice box and transferred to laboratory for further analysis. Physical parameters $\mathrm{pH}$, temperature and salinity was measured at both sites of each station using $\mathrm{pH}$ meter, thermometer and salinometer respectively.

In the laboratory $C$. rotundata and $T$. testudinum leaves were placed in sterile trays and washed gently three times with a spray of sterile filtered seawater to remove the unattached bacterial population along with any other debris. After washing the leaves, a sterile cotton swab was used to swipe the seagrass leaves. This swab was then transferred to a glass tube containing $30 \mathrm{ml}$ Alkaline Peptone Water (APW, $\mathrm{pH}-8.5, \mathrm{Hi}$-media) and incubated for $6-8$ hours at $37^{\circ} \mathrm{C}$ for enrichment of bacterial communities. $100 \mu \mathrm{L}$ of inoculation was pipetted out from each tube and transferred to sterile petridishes to which $15-20 \mathrm{ml}$ of sterilized Salt Yeast Extract Agar (SYEA, Hi-media) was added. After solidification plates were inverted and incubated at $37^{\circ} \mathrm{C}$ for 24 hours. Plates were observed for growth (appearance of colonies) after incubation and the plates with less growth were further incubated for 12 hours. Then colonies were counted using a colony counter and the morphology (colour) of the colonies were recorded. All the petriplates containing colonies between 30 - 300 were counted using the Quebec colony meter. Colonies with different morphology were picked and purity of the colonies was determined by streaking it on Nutrient Agar (NA, Hi-media) plates. These colonies were re-streaked onto fresh NA plates with 3 -streak method and incubated at $37^{\circ} \mathrm{C}$ for 12 hours. Pure isolates from these colonies were confirmed microscopically for purity and then transferred to agar slants or stabs for storage which was used for gram staining and biochemical tests. Routine biochemical test was carried out by following standard method and the isolates were characterized in accordance with the prevalent identification scheme appropriate for marine heterotrophic bacteria [26].

Thiosulphate Citrate Bile Salt (TCBS, Hi-media) agar was used for the culture of Vibrio sp. like organisms from seagrass, sediment and water samples. From pre-inoculated samples of seagrass, sediment and seawater in APW, $1 \mathrm{ml}$ was transferred to sterile glass tubes containing $10 \mathrm{ml}$ of sterilized $50 \%$ seawater. The tubes were vortexed and immediately filtered onto $0.45 \mu \mathrm{m}$ GF/F membrane Millipore filter paper and placed on TCBS agar plates. These plates were incubated for 12 to 18 hours and the colonies were counted and the individual colonies were streaked again on TCBS for obtaining pure cultures.

\section{Results}

The seawater $\mathrm{pH}$ was similar and salinity was lower in sediments than water column at both sites of Burmanala and Havelock. Heterotrophic bacterial count 
was 10-fold higher in sediment than water column and seagrass at both locations (Table 1). In Burmanala the seaward site had higher bacterial count than landward site, whereas the opposite trend was observed at Havelock site (Table 1). T. testudinum epiphytic bacterial count was similar with $C$. rotundata at Burmanala landward site and 2-fold higher at the seaward site of Havelock (Table $1)$.

16 different isolates with five different morphological features were obtained from the seagrass leaves, sediments and water column (Table 2). The white and grey coloured colonies accounted for $59 \%$ of total colonies and were dominated in sediment and sweater (Figure 1 and Figure 2). The green and yellow coloured colonies that represent Vibrio cholera like organisms (VCLO) and Vibrio parahaemolyticus like organisms (VPLO) represented $17.5 \%$ of the total colonies and were observed only on seagrass leaves. The sediment bacterial communities were dominated by Gram negative whereas the epiphytes of seagrass were dominated by Gram positive bacterial communities (Table 2). Identification of the isolates confirmed that more than 50\% represented Pseudomonas followed by Bacillus, Micrococcus, Aeromonas and Vibrios.

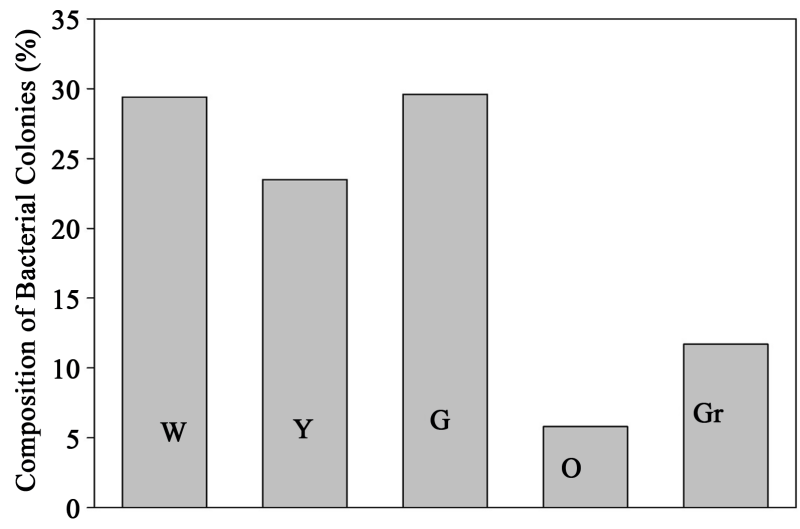

Figure 1. Total composition of different bacterial colonies based on morphology (colour) from Burmanala and Havelock. W (white), Y (yellow), G (grey), O (orange) and Gr (Green).

Table 1. Heterotrophic bacterial counts in water $(\mathrm{CFU} / \mathrm{ml})$ and sediment $(\mathrm{CFU} / \mathrm{mg})$ and in seagrass $(\mathrm{CFU} / \mathrm{ml})$ C. rotundata and T. testudinum at two sites of Burmanala and Havelock stations of Andaman Island.

\begin{tabular}{cccc}
\hline \multirow{2}{*}{ Station } & Sample & \multicolumn{2}{c}{ Bacterial Count $(\mathrm{CFU} / \mathrm{mg}$ or CFU $/ \mathrm{ml}) /$ Sites } \\
\cline { 3 - 4 } & & A & B \\
\hline \multirow{2}{*}{ Burmanala } & Water & $37.16 \times 10^{3}$ & $59.9 \times 10^{3}$ \\
& Sediment & $30.4 \times 10^{4}$ & $51.5 \times 10^{4}$ \\
& C. rotundata & $16.2 \times 10^{3}$ & $10.9 \times 10^{3}$ \\
Havelock & Water & $2.3 \times 10^{3}$ & $1.5 \times 10^{3}$ \\
& Sediment & $16 \times 10^{4}$ & $15.9 \times 10^{4}$ \\
& T. testudinum & $15 \times 10^{3}$ & $21.4 \times 10^{3}$ \\
\hline
\end{tabular}



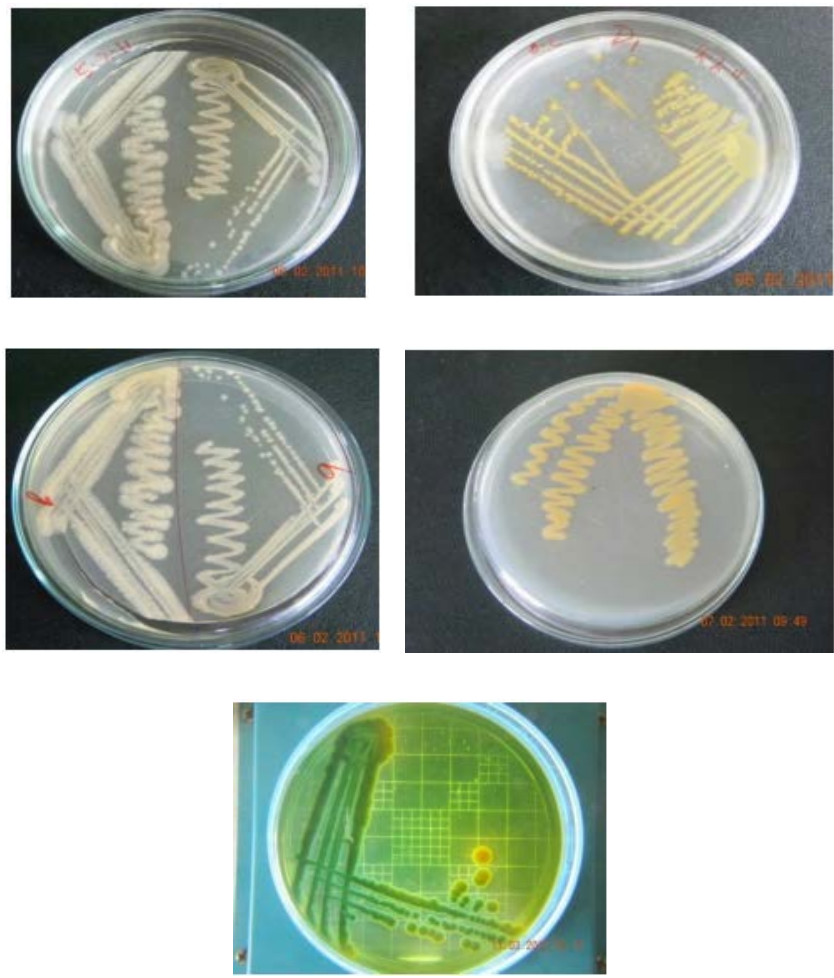

Figure 2. Nutrient agar plate streaks of White, Yellow, Grey, Orange and Green strains isolated from seagrass.

Table 2. Biochemical test of isolated bacterial colonies from Sediment (Sd), Seawater (Sw) and Seagrass (Sg) samples of Burmanala and Havelock stations of Andaman Island.

\begin{tabular}{|c|c|c|c|c|c|c|c|}
\hline \multirow{2}{*}{ No } & \multirow{2}{*}{ Colony } & \multirow{2}{*}{ Sample } & \multirow{2}{*}{$\begin{array}{c}\text { Gram } \\
\text { (+ve, -ve) }\end{array}$} & \multicolumn{4}{|c|}{ Biochemical Test } \\
\hline & & & & TSI & MIO & LIA & Citrate \\
\hline 1 & White & Sd & $+\mathrm{ve}$ & $\mathrm{K} / \mathrm{A} \mathrm{g}^{-} \mathrm{H}^{-}$ & $\mathrm{M}^{+} \mathrm{I}^{-} \mathrm{O}^{\mathrm{nr}}$ & $\mathrm{K} / \mathrm{A}(-\mathrm{ve})$ & $+\mathrm{ve}$ \\
\hline 2 & Grey & Sd & $-\mathrm{ve}$ & $\mathrm{K} / \mathrm{Ag}^{+} \mathrm{H}^{-}$ & $\mathrm{M}^{+} \mathrm{I}^{-} \mathrm{O}^{+}$ & $\mathrm{K} / \mathrm{A}(-\mathrm{ve})$ & $-\mathrm{ve}$ \\
\hline 3 & Grey & $\mathrm{Sd}$ & $+\mathrm{ve}$ & $\mathrm{K} / \mathrm{A} \mathrm{g}^{+} \mathrm{H}^{-}$ & $\mathrm{M}^{+} \mathrm{I}^{-} \mathrm{O}^{+}$ & $\mathrm{K} / \mathrm{A}(-\mathrm{ve})$ & $+\mathrm{ve}$ \\
\hline 4 & Grey & $\mathrm{Sd}$ & $-\mathrm{ve}$ & $\mathrm{A} / \mathrm{A} \mathrm{g}^{-} \mathrm{H}^{-}$ & $\mathrm{MIO}^{\mathrm{nr}}$ & $\mathrm{K} / \mathrm{A}(-\mathrm{ve})$ & $-\mathrm{ve}$ \\
\hline 5 & Yellow & Sd & $-\mathrm{ve}$ & $\mathrm{A} / \mathrm{A} \mathrm{g}^{-} \mathrm{H}^{-}$ & $\mathrm{MIO}^{\mathrm{nr}}$ & $\mathrm{nr}$ & $-\mathrm{ve}$ \\
\hline 6 & Orange & $\mathrm{Sd}$ & $-\mathrm{ve}$ & NG & NG & NG & NG \\
\hline 7 & White & Sd & $-\mathrm{ve}$ & $\mathrm{K} / \mathrm{A} \mathrm{g}^{+} \mathrm{H}^{-}$ & $\mathrm{M}^{+} \mathrm{I}^{-} \mathrm{O}^{+}$ & $\mathrm{K} / \mathrm{A}(-\mathrm{ve})$ & $-\mathrm{ve}$ \\
\hline 8 & Yellow & Sw & $-v e$ & $\mathrm{~A} / \mathrm{A} \mathrm{g}^{-} \mathrm{H}^{-}$ & $\mathrm{MIO}^{\mathrm{nr}}$ & $\mathrm{nr}$ & -ve \\
\hline 9 & White & Sw & $+\mathrm{ve}$ & $\mathrm{A} / \mathrm{A} \mathrm{g}^{-} \mathrm{H}^{-}$ & $\mathrm{MIO}^{\mathrm{nr}}$ & $\mathrm{K} / \mathrm{A}(-\mathrm{ve})$ & $-\mathrm{ve}$ \\
\hline 10 & White & Sw & $-\mathrm{ve}$ & $\mathrm{A} / \mathrm{Ag}^{-} \mathrm{H}^{-}$ & $\mathrm{MIO}^{\mathrm{nr}}$ & $\mathrm{nr}$ & $-\mathrm{ve}$ \\
\hline 11 & White & Sw & $+\mathrm{ve}$ & NG & NG & NG & NG \\
\hline 12 & Yellow & $\mathrm{Sg}$ & $-\mathrm{ve}$ & $\mathrm{A} / \mathrm{Ag}^{-} \mathrm{H}^{-}$ & $\mathrm{MIO}^{\mathrm{nr}}$ & $\mathrm{nr}$ & -ve \\
\hline 13 & Grey & $\mathrm{Sg}$ & +ve & $\mathrm{K} / \mathrm{N}$ & ND & ND & ND \\
\hline 14 & Green & $\mathrm{Sg}$ & +ve & $\mathrm{K} / \mathrm{N}, \mathrm{H}^{+}$ & $\mathrm{MIO}^{\mathrm{nr}}$ & $\mathrm{nr}$ & $-\mathrm{ve}$ \\
\hline 15 & Orange & $\mathrm{Sg}$ & $+\mathrm{ve}$ & $\mathrm{A} / \mathrm{Ag}^{-} \mathrm{H}^{-}$ & $\mathrm{MIO}^{\mathrm{nr}}$ & $\mathrm{nr}$ & $-\mathrm{ve}$ \\
\hline 16 & Grey & $\mathrm{Sg}$ & $-v e$ & $\mathrm{~K} / \mathrm{A} \mathrm{g}^{+} \mathrm{H}^{-}$ & $\mathrm{M}^{-} \mathrm{I}^{-} \mathrm{O}^{\mathrm{nr}}$ & $\mathrm{K} / \mathrm{A}(-\mathrm{ve})$ & - \\
\hline
\end{tabular}

A/A (Acid slant/Acid butt), K/A (Alkaline slant/Acid butt), $\mathbf{g}^{-}$(Gas (-ve)), $\mathrm{H}^{-}\left(\mathrm{H}_{2} \mathrm{~S}(-\mathrm{ve})\right.$ ), $\mathrm{K} / \mathrm{N}$ (no reaction), NG (no growth), $\mathbf{n r}$ (no reaction), $\mathbf{M}^{+}$(Motility positive), $\mathrm{O}^{+}$(Ornithine decarboxylase positive), $\mathrm{I}^{-}$ (Indole negative), ND (not done), TSI (Triple sugar Iron agar) MIO (Mobility Indole Ornithine), LIA (Lysine Iron Agar), Citrate (Simmons's citrate). 


\section{Discussion}

Intertidal seagrass leaves, sediments and water column were observed with various heterotrophic bacterial communities of Pseudomonas, Bacillus, Micrococcus, Vibrios and Aeromonas on seagrass leaves and in sediments and water column of Burmanala and Havelock of coastal Andaman Sea. Similar bacterial isolates were also observed from Andaman waters by [27] and in the intertidal ecosystem [28]. The microbial community observed in sediments were higher than water column and seagrass leaves, similar to the findings for Andaman Sea [27].

Both seagrass $C$. rotundata and $T$. testudinum harboured various heterotrophic bacterial communities, which agree with findings that seagrass leaves host diverse and potentially mutualistic bacterial isolates on their leaf surface [20]. Hosting diverse heterotrophic bacterial isolates was also observed on other seagrass leaves, such as Vibrios and Pseudomonas on Zostera marina [12] [20], H. stipulacea [29], Bacillus, Vibrios and Micrococcus on H. uninervis [23]. Bacillus, Vibrios and Pseudomonas as epiphytes on T. testudinum and C. rotundata of our results were similar to bacterial epiphytes of $T$. testudinum and $C$. rotundata in South China Sea [30]. We report the presence of Vibrios in seagrass leaves as epiphytes for the first time in Andaman Sea, however, other reports have observed Vibrios in seaweeds in these waters [28]. Heterotrophic bacterial communities in our studies were higher on $T$. testudinum than $C$. rotundata, similar observations have been made on $T$. testudinum than $C$. rotundata in South China Sea [30].

The heterotrophic bacterial diversity increases various microbial metabolic processes on the leaf surface of seagrass, such as sulphide oxidation, methane oxidation, iron reduction, nitrogen fixation and sulfate reduction that are influenced by seagrass leaves and certainly beneficial to the plant in oligotrophic waters [20] [30]. Though these microbes as epiphytes are beneficial to plants, their growth is also restricted on seagrass leaves by antimicrobial agents' seagrasses secrete only allowing certain microbes to be established on leaf surface as epiphytes [31] [32]. The bacterial community on T. testudinum was higher than $C$. rotundata in our studies which can be related to the quantity of antimicrobial compounds these seagrasses secrete [32] and their host-microbe interaction in a particular environment [33]. Though, similar types of microbes were observed on both $C$. rotundata and $T$. testudinum in our studies, the interaction between these microbes and seagrass are species-specific and remains same even in different environmental conditions [20]. However, the microbial epiphytes of seagrass leaves and in sediments were similar in our studies, except the Vibrios on seagrass leaves, which can be due to the different roles these microbial communities play on leaves and in sediments [20] [33]. Similarly, presence of Pseudomonas on the leaf surface is due to the excreted sugars from leaf surface [34] and Pseudomonas also helps the seagrass meadows to contribute to carbon bio-oxidation [35].

Bacterial colonies of sediments were dominated by gram negative bacterial 
colonies of Pseudomonas and Aeromonas, which agrees with the dominance of gram negative bacteria in marine sediments [36] due to the leaching of easily degradable sugars, organic acids and amino acids from seagrass roots and rhizomes into sediments [20] [37] and reduction of inorganic compounds like sulfate and acetogenic substances [37] [38]. The similarity of bacterial communities in sediment and seagrass leaves suggests the vertical input of organic matter from the seagrass leaves into sediment [39] that later colonise the sediments. Higher bacterial isolates from sediments also suggests that the microbes in sediments play a significant role in oligotrophic waters like Andaman Sea in cycling of carbon and nutrients and contributing to the productivity of these waters [40]. Presence of Bacillus and Pseudomonas in the sediments favours the seagrass in increasing stability of the seagrass meadows and stimulating mineralization of aerobic and anaerobic matter [41] [42] [43]. Presence of Pseudomonas in sediments suggests the presence of excreted sugars from roots and decaying leaves in sediments [34].

Bacterial colonies were higher in sediments followed by seagrass and water column in our studies, similar observations have been made in seagrass meadows elsewhere [30]. Lower bacteria in the water column is due to the low nutrient concentrations in oligotrophic Andaman waters as nutrient concentration plays a major role for growth of bacteria in water column [44].

Our results suggest that in seagrass meadows there is a closed loop of heterotrophic bacterial population as observed in seagrass leaves, sediments and water column. This closed loop represents the similar kind of active bacterial population that are attached on the seagrass leaves, found in the sediments and water column. This loop can be due to the nutrient limitation of these oligotrophic waters and being in a closed loop helps the bacteria in acquiring and cycling nutrients and maintaining productivity of the ecosystem. Both seagrass was associated with diverse heterotrophic bacterial isolates which can be related to the diverse compounds seagrasses release as by-products of primary productivity. This raises the need of understanding the plant-microbe interaction in details in oligotrophic waters of Andaman Sea, which can provide us better understanding of the role heterotrophic bacterial population plays in these intertidal seagrass meadows. However, the presence of pathogens like Vibrios in Andaman waters reflects the effects of human impacts on the coastal ecosystems and that can affect the beneficial epiphytic population of seagrass through competition and transfer of pathogens to higher food webs by seagrass depended herbivory.

\section{Acknowledgements}

The research project was carried out at Department of Ocean Studies and Marine Biology, Pondicherry University, India. I am thankful to Head of the Department Dr. P. M. Mohan for providing the necessary support for carrying out the research work. I heart fully thank Kishore Kumar for helping me in collection of samples. 


\section{Conflict of Interest}

The author declares that there is no conflict of interest between any funding agencies or organizations for this research work.

\section{References}

[1] Rao, D.V., Chandra, K. and Devi, K. (2013) Endemic Fauna of Andaman and Nicobar Islands. Zoological Survey of India, $182 \mathrm{p}$.

[2] Thangaradjou, T., Sivakumar, K., Nobi, E.P. and Dilipan, E. (2010) Distribution of Seagrasses along the Andaman and Nicobar Islands: A Post Tsunami Survey. Recent Trends in Biodiversity of Andaman and Nicobar Islands, 157-160.

[3] Hemminga, M.A. and Duarte, C.M. (2000) Seagrass Ecology. Cambridge University Press, Cambridge, 298 p. https://doi.org/10.1017/CBO9780511525551

[4] Short, F., Carruthers, T., Dennison, W. and Waycott, M. (2007) Global Seagrass Distribution and Diversity: A Bioregional Model. Journal of Experimental Marine Biology and Ecology, 350, 3-20. https://doi.org/10.1016/j.jembe.2007.06.012

[5] Hamisi, M., Díez, B., Lymio, T. and Ininbergs, K. (2013) Epiphytic Cyanobacteria of the Seagrass Cymodocea rotundata: Diversity, Diel nifH Expression and Nitrogenase Activity. Environmental Microbiology Reports, 5, 367-376. https://doi.org/10.1111/1758-2229.12031

[6] Erwin, K.L. (2009) Wetlands and Global Climate Change: The Role of Wetland Restoration in a Changing World. Wetlands Ecology and Management, 17, 71-84. https://doi.org/10.1007/s11273-008-9119-1

[7] Coles, R.G., McKenzie, L.J., Rasheed, M.A. and Mellors, J.E. (2007) Status and Trends of Seagrass Habitats in the Great Barrier Reef World Heritage Area. Report to the Marine and Tropical Sciences Research Facility. Reef and Rainforest Research Centre Limited, Cairns, 122.

[8] Borowitzka, M.A., Lavery, P. and Van Keulen, M. (2005) Epiphytes of Seagrass. Seagrass Biology. Springer, Netherlands, 1-21.

[9] Deming, J.W. and Baross, J.A. (1993) The Early Diagenesis of Organic Matter: Bacterial Activity. Org. Geochem. Topics in Geobiology, Springer, Boston, MA, Vol. 11, 119-144. https://doi.org/10.1007/978-1-4615-2890-6_5

[10] Hagström, Á., Azam, F., Anderson, A. and Wikner, J. (1988) Microbial Loop in an Oligotrophic Pelagic Marine Ecosystem: Possible Roles of Cyanobacteria and Nanoflagellates in the Organic Fluxes. Marine Ecology Progress Series, 49, 171-178. https://doi.org/10.3354/meps049171

[11] Belofsky, G.N., Jensen, P.R. and Fenical, W. (1999) Sansalvamide: A New Cytotoxic Cyclic Depsipeptide Produced by a Marine Fungus of the Genus Fusarium. Tetrahedron Letters, 40, 2913-2916. https://doi.org/10.1016/S0040-4039(99)00393-7

[12] Kurilenko, V.V., Ivanova, E.P. and Mikhailov, V.V. (2001) Zonal Distribution of Epiphytic Microorganisms on the Eelgrass Zostera marina. Microbiology, 70, 372-373. https://doi.org/10.1023/A:1010475916224

[13] Novak, R. (1984) A Study in Ultra-Ecology: Microorganisms on the Seagrass Posidonia oceanica (L.) DELILE. Marine Ecology, 5, 143-190. https://doi.org/10.1111/j.1439-0485.1984.tb00313.x

[14] Pinckney, J.L. and Micheli, F. (1998) Microalgae on Seagrass Mimics: Does Epiphyte Community Structure Differ from Live Seagrass? Journal of Experimental Marine Biology and Ecology, 221, 59-70. 
https://doi.org/10.1016/S0022-0981(97)00115-9

[15] Capone, D.G. and Taylor, B.F. (1977) Nitrogen Fixation (Acetylene Reduction) in the Phyllosphere of Thalassia testudinum. Marine Biology, 40, 19-28.

https://doi.org/10.1007/BF00390623

[16] Cornelisen, C.D. and Thomas, F.I.M. (2002) Ammonium Uptake by Seagrass Epiphytes: Isolation of the Effects of Water Velocity using an Isotope Label. Limnology and Oceanography 47, 1223-1229. https://doi.org/10.4319/lo.2002.47.4.1223

[17] Pereg, L.L., Lipkin, Y. and Sar, N. (1994) Different Niches of the Halophila stipulacea Seagrass Bed Harbour Distinct Populations of Nitrogen Fixing Bacteria. Marine Biology, 119, 327-333.

[18] Küsel, K., Pinkart, H.C., Drake, H.L. and Devereux, R. (1999) Acetogenic and Sulfate-Reducing Bacteria Inhabiting the Rhizoplane and Deep Cortex Cells of the Sea Grass Halodule wrightii. Applied and Environmental Microbiology, 65, 5117-5123.

[19] Cifuentes, A., Anton, J., Benlloch, S., Donnelly, A., Herbert, R.A. and Rodriguez-Valera, F. (2000) Prokaryotic Diversity in Zostera noltii-Colonized Marine Sediments. Applied and Environmental Microbiology, 66, 1715-1719. https://doi.org/10.1128/AEM.66.4.1715-1719.2000

[20] Crump, B.C. and Koch, E.W. (2008) Attached Bacterial Populations Shared by Four Species of Aquatic Angiosperms. Applied and Environmental Microbiology, 74, 5948-5957. https://doi.org/10.1128/AEM.00952-08

[21] Bagwell, C.E., La Rocque, J.R., Smith, G.W. and Polson, S.W. (2002) Molecular Diversity of Diazotrophs in Oligotrophic Seagrass Bed Communities. FEMS Microbiology Ecology, 39, 113-119.

[22] Williams, C.J., Boyer, J.N. and Jochem, F.J. (2008) Microbial Activity and Carbon, Nitrogen and Phosphorous Content in a Subtropical Seagrass Estuary (Florida Bay): Evidence for Limited Bacterial Use of Seagrass Production. Marine Biology, 156, 341-353. https://doi.org/10.1007/s00227-008-1087-8

[23] Wahbeh, M.I. and Mahasneh, A.M. (1984) Heterotrophic Bacteria Attached to Leaves, Rhizomes and Roots of Three Seagrass Species from Aqaba (Jordan). Aquatic Botany, 20, 87-96. https://doi.org/10.1016/0304-3770(84)90029-9

[24] Garcia-Martinez, M., Lopez-Lopez, A., Calleja, M.L., Marba, N. and Duarte, C.M. (2009) Bacterial Community Dynamics in a Seagrass (Posidonia oceanica) Meadow Sediment. Estuaries Coasts, 32, 276-286. https://doi.org/10.1007/s12237-008-9115-y

[25] Blum, L.K., Mills, A.L., Zieman, J.C. and Zieman, R.T. (1988) Abundance of Bacteria and Fungi in Seagrass and Mangrove Detritus. Marine Ecology Progress Series, 42, 73-78. https://doi.org/10.3354/meps042073

[26] Buchanan, R.E. and Gibbons, N.E. (1974) Bergey's Manual of Determinative Bacteriology. 8th Edition, Williams and Wilkins, Baltimore, $1268 \mathrm{p}$.

[27] Devi, V. (2004) Studies on Heterotrophs of Sesostris Bay, Andaman. M.Sc. Dissertation, Pondicherry University, Pondicherry.

[28] Murthy, K.N., Mohanraju, R., Karthick, P. and Ramesh, C.H. (2013) Epiphytic Vibrio from the Seaweeds of Andaman Island, India. Seaweed Research and Utilization, 35, 220-225.

[29] Weidner, S., Arnold, W., Stackebrandt, E. and Puhler, A. (2000) Phylogenetic Analysis of Bacterial Communities Associated with Leaves of the Seagrass Halophila stipulacea by a Culture-Independent Small-Subunit rRNA Gene Approach. Applied and Environmental Microbiology, 39, 22-31. 
[30] Jiang, Y.F., Ling, J., Wang, Y.S. and Chen, B. (2015) Cultivation Dependent Analysis of the Microbial Diversity Associated with the Seagrass Meadows in Xincun Bay, South China Sea. Ecotoxicology, 24, 1540-1547. https://doi.org/10.1007/s10646-015-1519-4

[31] Bushmann, P.J. and Ailstock, M.S. (2006) Antibacterial Compounds in Estuarine Submersed Aquatic Plants. Journal of Experimental Marine Biology and Ecology, 331, 41-50. https://doi.org/10.1016/j.jembe.2005.10.005

[32] Newby, B.M.Z., Cutright, T., Barrios, C.A. and Xu, Q.W. (2006) Zosteric Acid-An Effective Antifoulant for Reducing Fresh Water Bacterial Attachment on Coatings. Journal of Coatings Technology and Research, 3, 69-76. https://doi.org/10.1007/s11998-006-0007-4

[33] Andrews, J.H. and Harris, R.F. (2000) The Ecology and Biogeography of Microorganisms of Plant Surfaces. Annual Review of Phytopathology, 38, 145-180. https://doi.org/10.1146/annurev.phyto.38.1.145

[34] Hirano, S.S. and Upper, C.D. (2000) Bacteria in the Leaf Ecosystem with Emphasis on Pseudomonas Syringae-A Pathogen, Ice Nucleus, and Epiphyte. Microbiology and Molecular Biology Reviews, 64, 624-653. https://doi.org/10.1128/MMBR.64.3.624-653.2000

[35] Tolli, J.D., Sievert, S.M. and Taylor, C.D. (2006) Unexpected Diversity of Bacteria Capable of Carbon Monoxide Oxidation in a Coastal Marine Environment, and Contribution of the Roseobacter-Associated Clade to Total CO Oxidation. Applied and Environmental Microbiology, 72, 1966-1973. https://doi.org/10.1128/AEM.72.3.1966-1973.2006

[36] Moriarty, D.J.W. and Hayward, A.C. (1982) Ultrastructure of Bacteria and the Proportion of Gram-Negative Bacteria in Marine Sediments. Microbial Ecology, 8, 1-14. https://doi.org/10.1007/BF02011456

[37] Küsel, K., Trinkwalter, T., Drake, H.L. and Devereux, R. (2006) Comparative Evaluation of Anaerobic Bacterial Communities Associated with Roots of Sub-Merged Macrophytes Growing in Marine or Brackish Water Sediments. Journal of Experimental Marine Biology and Ecology, 337, 49-58. https://doi.org/10.1016/j.jembe.2006.06.004

[38] Jensen, S.I., Kühl, M. and Priemé, A. (2007) Different Bacterial Communities Associated with the Roots and Bulk Sediment of the Seagrass Zostera marina. FEMS Microbiology Ecology, 62, 108-117. https://doi.org/10.1111/j.1574-6941.2007.00373.x

[39] Kristensen, E. and Holmer, M. (2001) Decomposition of Plant Materials in Marine Sediment Exposed to Different Electron Acceptors $\left(\mathrm{O}_{2}^{-}, \mathrm{NO}_{3}{ }^{-}\right.$, and $\left.\mathrm{SO}_{4}{ }^{2-}\right)$, with Emphasis on Substrate Origin, Degradation Kinetics, and the Role of Bioturbation. Geochimica et Cosmochimica Acta, 65, 419-433. https://doi.org/10.1016/S0016-7037(00)00532-9

[40] Fenchel, T. (2000) The Microbial Loop-25 Years Later. Journal of Experimental Marine Biology and Ecology, 366, 99-103. https://doi.org/10.1016/j.jembe.2008.07.013

[41] Welsh, D.T. (2000) Nitrogen Fixation in Seagrass Meadows: Regulation, Plant-Bacteria Interactions and Significance to Primary Productivity. Ecology Letters, 3, 58-71. https://doi.org/10.1046/j.1461-0248.2000.00111.x

[42] Holmer, M. and Bondgaard, E.J. (2001) Photosynthetic and Growth Response of Eelgrass to Low Oxygen and High Sulfide Concentrations during Hypoxic Events. Aquatic Botany, 70, 29-38. https://doi.org/10.1016/S0304-3770(00)00142-X 
[43] Jensen, S.I., Kuhl, M., Glud, R.N., Jørgensen, L.B. and Prieme, A. (2005) Oxicmicrozones and Radial Oxygen Loss from Roots of Zostera marina. Marine Ecology Progress Series, 293, 49-58. https://doi.org/10.3354/meps293049

[44] Dietz, H., Fischer, M. and Schmid, B. (1999) Demographic and Genetic Invasion History of a 9-Year-Old Roadside Population of Bunias orientalis L. (Brassicaceae). Oecologia, 120, 225-234. https://doi.org/10.1007/s004420050852 